Birte Brekketo

\title{
Taswir - perspektiver fra en meningsutveksling om figurativ fremstilling i sunni-islam
}

\section{Sammendrag}

På hvilke måter angår det oss hva islamske laerde måtte mene om figurativ fremstilling? Vi lever i massemedienes og de sosiale medienes tidsalder der visuelle budskap når ut til store og sammensatte betraktergrupper. Stadig flere av oss mestrer avanserte kommunikasjonsmedier, men vår kunnskap om forskjellige visuelle tradisjoner har ikke фkt $i$ takt med den teknologiske utviklingen. Denne artikkelen går tett på tradisjonstrekk som er mindre kjente for mange $i$ den vestlige verden, men som jevnlig kommer til uttrykk $i$ både norsk og global offentlighet: Innenfor sunni-islamsk visuell tradisjon foregår det en fortlopende meningsutveksling om virkningene av figurativ fremstilling (taswir). De ulike synspunktene som lar seg høre, bygger på omhyggelig fortolkning av religiфse kilder, og de formidles ofte $i$ polemiske former på internett. Den foreliggende oversikten over bredden og nyansene på taswir-feltet er blitt til ved samling og strukturering av stoff over lang tid. Målsettingene med $\stackrel{a}{a}$ presentere denne oversikten er å inspirere leseren til å sende tankene $i$ nye retninger. For det første får leseren innblikk $i$ hvordan forestillinger om det visuelle utvikles, prøves ut og konsolideres $i$ en sunni-islamsk tradisjonskontekst. For det andre plasseres taswir i en global samtidskontekst, $i$ en posisjon som synliggjør det presserende behovet for en debatt om kompetanse og sensibilitet $i$ samtidens visuelle kommunikasjonssituasjon.

Nøkkelord: Visuelle tradisjoner, figurativ representasjon i islam, verdensomfavnende kommunikasjon, moderne media

La meg åpne artikkelen med en klargjøring av hvem jeg sikter til med det store «vi» $\mathrm{i}$ innledningen: Samtiden karakteriseres av vekselvirkninger og flyt mellom lokale, nasjonale og globale nivåer i kommunikasjonen. I denne settingen opererer kommunikasjonsdeltakere som har bakgrunn i forskjellige tradisjoner, og som følgelig har forskjellige forutsetninger for å konstruere og tolke visuelle budskap. Kommunikasjonsstrømmene knytter alle sammen i et mangfoldig og mer motsetningsrommende «vi», enn det hver og en av oss ofte er klar over.

I denne artikkelen vil jeg presentere sunni-islamske perspektiver på figurativ fremstilling, - perspektiver som på avgjørende punkter står i kontrast til tenkning om bilder i vestlig tradisjon. Én målsetting med artikkelen er å formidle bredden og nyansene i sunniislamsk argumentasjon rundt figurativ fremstilling, en annen målsetting er å gi ikkemuslimske kommunikasjonsdeltakere et grunnlag for videre refleksjon. Det er heller ikke usannsynlig at kommunikasjonsdeltakere med utgangspunkt i én bestemt muslimsk tradisjon vil finne utfyllende informasjon i breddefremstillingen av lærd argumentasjon på feltet.

En tredje - men ikke mindre viktig - målsetting er å invitere til debatt om visuelle kommunikasjonsvilkår i den multikulturelle samtiden. Dessverre har de seneste årene brakt flere eksempler på hvordan kommunikasjonsbrist avler vrede eller vantro forbauselse. Det er nærliggende å peke på de alvorlige konsekvensene som fulgte da Jyllands-Posten i 2005 publiserte karikaturtegninger som forestilte profeten Mohammed. Muligens valgte den danske avisredaksjonen med overlegg en provokativ formgivning av budskapet, men at episoden skulle innlede en storm av voldsomme reaksjoner fra muslimsk hold og år med politisk uro, det hadde nok ikke redaksjonen forutsett. Både Jyllands-Postens redaktør Flemming Rose og den danske statsministeren Anders Fogh Rasmussen fant det i ettertid nødvendig å presisere 
verbalt hva tegningene var ment å uttrykke $\mathrm{i}$ et fors $\varnothing \mathrm{k}$ på å ta brodden fra budskapet (Alhassan, 2008, s. 49; Hervik, 2008, s. 66; Klausen, 2009).

Det er også verd å nevne et eksempel av en helt annen karakter, men som like fullt har i seg spenningene mellom ulike syn på visuelle virkemidler og kommunikasjon. I 2001 sprengte Taliban i stykker buddhaene i Bamiyan, en gjerning som vekket indignasjon og forskrekkelse i vide kretser, ikke minst blant kulturinteresserte. Ut fra en vestlig tradisjonsbakgrunn var det vanskelig å tolke gjerningen som annet enn vandalisme, eventuelt som et fanatisk utslag av islamsk ikonoklasme. Det var imidlertid liten nysgjerrighet og liten interesse for å søke dypere, etter forklaringer i gjerningsmennenes virkelighetsforståelse og visuelle opplæring $\mathrm{i}$ en tradisjon: Hva drev dem til sprengningen, og hvorfor var det maktpåliggende for dem å tilintetgjøre statuene?

Tilbake til kjernen i saken: Erfaringer tilsier at visuell kommunikasjon som hviler på få kontaktpunkter vekker mistenksomhet fremfor forståelse. Slik kommunikasjon er ofte feilslått (hvis den ikke er bevisst provokativ), og den skjerper latente konfrontasjonslinjer mellom kommunikasjonsdeltakerne. Hva kan og vil vi gjøre for å bedre kommunikasjonens treffsikkerhet? Vil mer kompetanse hjelpe oss å takle en samtid der bilder distribueres lokalt og globalt på et øyeblikk, og der kommunikasjonsdeltakeres ulike tradisjonsbakgrunner bringes direkte sammen uten støtdempende mellomledd? Bør vi alle, uansett bakgrunn, ta et ansvar for å tilegne oss kunnskaper som går utover vår primære visuelle opplæring? Og sist, men ikke minst: På hvilke måter ønsker vi å balansere ytringsfrihet mot hensynet til annerledes tenkende?

Det er på høy tid å stille disse spørsmålene.

\section{Hva er taswir?}

I årene fra 2010 til 2012 hadde jeg lange opphold på videregående skoler i Oslo. Jeg intervjuet norskpakistanske muslimer om deres bruk av figurative bilder. Målet var å finne ut hva slags visuelle praksiser ungdommene utvikler under krysspress fra vestlig figurasjons-orientert tradisjon og islamsk figurasjons-problematiserende tradisjon. Unders $\varnothing$ kelsene fant sin form i et doktorgradsarbeid om hvordan unge norske muslimer forholder seg til islams normative retningslinjer for bruk av figurativ fremstilling (Brekketo, 2013).

Da ungdommene begynte å fortelle fra sine hverdagsliv, berørte de komplekse problemstillinger og refererte til tradisjonsoverført kunnskap de har om visuelle uttrykksformer innenfor sunni-islam. Jeg erfarte tidlig i undersøkelsen at det var nødvendig å konstruere en bakgrunn for fortolkningen av de mange beretningene.

Min første innskytelse var å søke etter relevant informasjon i litteratur, men der var det lite å finne: Holdninger til figurativ fremstilling i islam var mangelfullt dekket. Jeg kom over spredte betraktninger $\mathrm{i}$ tekster av islamske lærde, muslimske intellektuelle og vestlige forskere, men ingen systematisk og nyansert oversikt over emnet. Imidlertid fant jeg ut at figurativ fremstilling er et høyst aktuelt og omdiskutert tema blant sunni-muslimer, og kommunikasjonsplattformen er gjerne internett. Det finnes nettsteder der lærde diskuterer skarpt, det finnes diskusjonsfora for praktiserende muslimer, og det finnes rådgivningstjenester der lærde konsulteres i spørsmål som vedrører bruk av figurativ fremstilling. I alle disse sammenhengene refereres det til taswir, som er det arabiske begrepet for å fremstille mentale forestillinger i figurativ visuell form. Språket som brukes på nettstedene er engelsk fordi de er spesielt rettet mot muslimer som lever i diaspora. Muslimer har vidt forskjellige morsmål, og det er ingen selvfølge at de behersker arabisk. Engelsk har kommet til å fungere som et lingua franca, antakelig på grunn av de store diaspora-gruppene $\mathrm{i}$ Canada, Storbritannia og USA. På nettstedene oppgis spesialbegreper og tekniske begreper alltid på arabisk (i kursiv og innenfor parentes) for presisjonens skyld. Det er en stor fordel for alle som ikke behersker arabisk (for eksempel meg) at så mye informasjon formuleres direkte 
på engelsk fra de muslimske fortolkningsmiljøene. Mange av disse nettstedene har jeg fulgt med på over tid for å samle stoff.

Dette store korpus av uensartet materiale fra litteratur og nett - til dels bestående av engasjerte og polemiske ytringer - har vært krevende å håndtere: Jeg har søkt etter både sammenhenger og nyanser når jeg har sortert og systematisert stoffet. I det følgende vil jeg dele den innsikten jeg har fått om taswir med leserne.

\section{Sunni-muslimske reaksjoner på modernitet og globalisering}

Innledningsvis faller det naturlig å plassere taswir-feltet i en bredere historisk sammenheng:

Én av grunnene til at islamske lærde fokuserer på figurativ fremstilling, er at medierevolusjonen har satt temaet på dagsordenen. Fremveksten av nye medier har ført til at bruken av figurative bilder har endret seg: Slike bilder inngår i helt andre kontekster i dag enn den gang kildetekstene ble skrevet og islamske fortolkningsprinsipper ble utformet. Nye medier utfordrer kildefortolkerne fordi de produserer figurative bilder som ikke passer inn i de etablerte bildekategoriene. Etter hvert som visuell kommunikasjon med nye medier griper om seg, blir spørsmålene om figurativ fremstilling stadig flere, og mer komplekse, for islamske lærde å svare på.

En annen grunn til at taswir-feltet er blitt aktualisert, ligger i nære historiske hendelser. Vestlige lands tilstedeværelse i muslimske samfunn har provosert. Samfunnsforandringer som følge av nærværet har skapt behov for å definere på nytt, eller å omdefinere, muslimsk identitet både religiøst og politisk. I identitetsprosessene har det vært viktig ikke bare å poengtere det særegne ved islam, men også å poengtere på hvilke punkter islam skiller seg fra andre religioner og kulturuttrykk. Flere sunni-muslimske reformbevegelser vokste frem i overgangen mellom 1700- og 1800-tallet: Ulike retninger som for eksempel wahhabisme, salafisme, deobandi og barelwi ble sterke (Roy, 2004, s. 233-238; Kepel, 2002, s. 219-220; Metcalf, 1982; Sanyal, 1996; Kühle, 2012; Ahmed, 2004 [1992], s. 30; Halldén, 2006, s. 63 65). Reformbevegelsene har fortsatt å utvikle seg frem mot samtiden, men i migrasjonenes tidsalder har flere av dem skiftet karakter. Religionshistorikeren Meredith B. McGuire beskriver en generell og verdensomspennende tendens der personlig og opplevd religiøsitet blir mer toneangivende - i faglitteraturen benevnt som religiøs «revival» (McGuire, 2008; Berger, 2007; Ammerman 2007; Roy 2004, s. 148-149; Roy, 2007, s. 69). Islam gir i vesentlig grad retning til denne tendensen, idet nye forestillinger om religionens status $\mathrm{i}$ samfunnet er i ferd med å befeste seg hos mange muslimer. Islamhistorikeren Olivier Roy peker på hvordan islam i moderne tid er blitt «deterritorialisert». Han sikter til at båndene mellom religiøs utøvelse og kulturell kontekst blir forrykket fordi et stort antall muslimer lever som minoriteter i ikke-muslimske samfunn (Roy, 2004, s. 2-3, 5, 18-19; Roy, 2007, s. 65-67; Lewitt, 2007, s. 114). Idéen om umma, det islamske fellesskapet, relateres ikke lenger til geografiske områder eller muslimske miljøer, men oppfattes som et overbyggende, transnasjonalt verdifellesskap. Forskerne omtaler fenomenet umma som et eksempel på «imaginært fellesskap», i den forstand at mennesker med til dels ulike religiøse prioriteringer opplever at bekjennelsen til islam knytter dem sammen (Anderson, 1992 [1983], s. 6-7; McGuire, 2008, s. 205; Roy, 2004, s. 106-107). Hvordan umma-begrepet nærmere defineres, vil det være ulike meninger om blant muslimer. Det bør likevel nevnes at nyfundamentalistiske og radikaliserte grupperinger, ofte benevnt som salafistiske, har arbeidet aktivt via internett for å tydeliggjøre sine oppfatninger av hva umma innebærer, og disse synspunktene fenger internasjonalt (Roy, 2004, s. 2, 6, 139, 257-259; Roy, 2007, s. 72-73; Kepel, 2002, s. 193-195, 219. Merk for $\varnothing v$ rig at IS som proklamerte opprettelsen av et kalifat 29. juni 2014, mener at dette skal oppfattes som gyldig så vel lokalt som globalt). 
Den uoversiktlige situasjonen som beskrives ovenfor, inviterer til et nærblikk på forholdet mellom praktiserende muslimer og religiøse normer. Hvordan formes normer i islam?

Ofte betegnes islam som en lovreligion. Med det menes at loven (sharia) er nedfelt $\mathrm{i}$ selve åpenbaringen, uttrykt gjennom Koranen, og at den må tolkes for å kunne praktiseres. Fortolkningsarbeidet har tradisjonelt vært utført av lærde som har spesialisering i islamsk rettslære (fiqh) fra anerkjente læresteder (Vogt, 2005, s. 80-81; Vogt, 2007, s. 61-62; Ramadan, 2004, s. 82-83, 92; Vikør, 2003, s. 10, 13-14, 42; Roald, 2004, s. 85). I dag utfordres disse tradisjonelle lærde av fortolkere med variert studiebakgrunn. Det er særlig tilnærmingen til kildetekstene som er ulik blant samtidens lærde: De tradisjonstro holder seg strengt til rettslærens fremgangsmåter (taqlid), mens nyfundamentalister, radikaliserte og moderate gjerne går direkte til kildene (ijtihad) (Roald, 2004, s. 163-167; Vikør, 2003, s. 219220, 245; Kepel, 2002, s. 219-220; Doi, 1989, s. 153; Larsson, 2009, s. 479-480). Her er det viktig å poengtere at det parallelt med migrasjon og medierevolusjon er skjedd en autoritetsspredning i islam.

I denne historiske, politiske og religiøse konteksten har meningsutvekslingene om figurativ fremstilling latt seg høre med fornyet kraft i sunni-muslimske fortolkningsmiljøer. Islamske lærde med ulik bakgrunn og utdannelse har tolket religiøse kildetekster og bygget videre på eldre argumentasjon om figurative bilder. Fortolkningsaktivitetene har resultert i detaljerte og til dels motstridende argumenter om alt fra figurative fremstillingsteknikker til bruk av figurative bilder i ulike situasjoner (Brekketo, 2013). ${ }^{1}$

Islamske lærde legger alltid vekt på å formulere religiøst holdbare argumenter, men i et videre perspektiv kan meningsutvekslingene om taswir også leses som motstand mot teknologisk homogenisering av visuelle budskapers formgivning, for en stor del styrt av vestlige aktører (Grabar, 2006, s. 42; Ahmed, 2004 [1992], s. 223). Interessant er det at samtidssituasjonen viser likhetstrekk med en tidlig fase i islams historie da bekjempelsen av figurative gudebilder markerte islamsk holdning til før-islamske og ikke-islamske kulturuttrykk: Taswir er i ferd med å bli en symbolsak, spesielt i nyfundamentalistiske og radikaliserte miljøer.

Meningsutvekslingene om taswir kan følgelig tolkes som reaksjoner på vestlig modernisme, men også som videreføring i moderne form av islamske oppfatninger som har røtter langt tilbake i tid.

\section{Hadithlitteraturen}

Når det gjelder visuelle uttrykk, gir Koranen tydelige og negative signaler om én spesiell bruk av figurative bilder: Slike bilder fordømmes når de kommer mellom den troende og Gud (Koranen, 6.74, 21.53-55; Mirza, 2005, s. 414-428; Hodgson, 1964, s. 229). De få korantekstene som handler om det visuelle, gir for spinkelt grunnlag til å trekke konklusjoner om generelle holdninger til figurativ fremstilling. I taswir-problematikken begrunnes derfor argumentene om figurativ fremstilling med tekster fra hadithlitteraturen, som, i motsetning til Koranen, kommer med mange betraktninger rundt bilder og bildebruk. Hadithtekstene handler om profeten Mohammeds livsførsel, om hva han har sagt eller gjort, og om hvilke gjerninger han har misbilliget eller bifalt. Hadithlitteraturen fungerer som fortolkningsramme for Koranen, den betegnes som Profetens tradisjon (sunna), og den gir forbilder for livsførsel blant praktiserende muslimer.

En hadith består av innhold (matn) og fortellerkjede (isnad). I vurderingen av en hadiths troverdighet vektlegger lærde at fortellerkjeden kan føres tilbake til de menneskene som har omgitt Profeten eller møtt ham, altså til øyenvitner. Troverdigheten blir ytterligere styrket dersom en hadith er mangfoldig (mutawatir), det vil si overlevert nærmest likelydende gjennom flere fortellerkjeder. 
I dag ansees hadith-samlingene til al-Bukhari og Muslim som mest troverdige og autentiske i sunni-islam, og det er disse man finner flest henvisninger til. Tekstsamlingene er store i omfang, for eksempel består al-Bukharis materiale av over 7000 hadithtekster (beretninger med ulike varianter) systematisert i 3450 kapitler (Vikør, 2003, s. 41-5, 96-99; Roald, 2004, s. 69-73; Vogt, 2005, s. 34-38; Goldziher, 1981 [1910], s. 37-41; Schacht, 1979 [1950], s. 3-4, 36-37).

Dersom autentiske hadithtekster er samstemte og klare, og dersom de utfyller hverandre, lar meningen seg utlede direkte. Dersom tekstene er uklare, eller dersom de synes å motsi hverandre, må lærde anvende fortolkningsprinsipper fra den islamske rettslæren (fiqh) (Vikør, 2003, s. 10-11, 13-14, 41-42; Vogt, 2005, s. 80-81; Vogt, 2007, s. 61-62; Roald, 2004, s. 84-85). Hadithtekstene som handler om figurativ fremstilling oppfattes ulikt, og det er utviklet et bredt spekter av fortolkninger. De lærdes meninger om figurativ fremstilling lar seg likevel sammenfatte i fire overordnede punkter, som utdypes i det følgende.

\section{Risiko for bildedyrkelse og polyteisme}

Én bestemt form for figurativ fremstilling vekker særlig bekymring hos islamske lærde, nemlig det antropomorfe, menneskelike bildet.

I islam blir Guds enhet (tawhid) oppfattet som absolutt og overordnet. Det er en utbredt oppfatning at Gud ikke kan beskrives. Man tenker seg at Gud manifesterer seg gjennom skaperverket, men aldri som noe menneskeliknende. Videre tenker man seg at alt som konkurrerer med Gud om oppmerksomhet, kvalifiserer til betegnelsen avgud: Det være seg drift etter rikdom, ønske om makt, besettelse av en person, begeistring for et bilde. Det å spre oppmerksomheten eller rette tilbedelsen mot flere mål blir betegnet som polyteisme (shirk), og vurdert som en alvorlig villfarelse (Koranen, 4.116; Roald, 2004, s. 108, 156-157, 174; Vogt, 2005, s. 348; Nasr, 1989, s. 312-315).

Forståelsen av polyteisme har historisk sett vært nært knyttet til kampen mot gudebilder med antropomorfe former. I før-islamsk tid var det en utbredt skikk på den arabiske halvøy å reise statuer og monumenter til minne om avdøde. Med tiden fikk forfedrenes minnesmerker status som guddommelige $\mathrm{i}$ folks forestillingsverden. Flere islamske lærde mener derfor at minnesmerker i visuell form bør unngås på grunn av risikoen for å utvikle bildedyrkelse og polyteisme. En bedre måte å hedre noen på, er å holde deres minne levende $\mathrm{i}$ tankene. A reise statuer eller opprette gravmonumenter oppfattes som en tilbakevending til antikke og hedenske skikker (Al-Qaradawi, 2003 [1960], s. 86-87, 89; Mirza, 2005, s. 414).

Slik forklares sammenhengen mellom gudebilder og minnebilder. Men hva med bruk av bilder med antropomorfe former $\mathrm{i}$ andre kontekster? I forlengelsen av argumentasjonen rundt gudebilder og minnebilder retter lærde oppmerksomheten mot hvilke virkninger antropomorfe bilder har på betraktere, det vil si på dem som eier, bruker eller på andre måter forholder seg til slike bilder.

Det antropomorfe bildet oppfattes som en aktør med mulighet til å øve innflytelse på omgivelsene. Lærde er særlig opptatt av at denne bildetypen har et farlig potensiale - det involverer en relasjon som fra betrakterens side oppleves som gjensidig. Gjenkjennelse av ansikter har en nøkkelfunksjon når det gjelder å skape identifikasjon eller kontakt mellom mennesker. På grunnlag av hadithtekster som advarer mot ansikters appell, er en del lærde derfor spesielt negative overfor avbildede ansiktstrekk.

En variant av forestillingen om bildets aktørkvaliteter finnes i hadithtekster der det gis uttrykk for at antropomorfe bilder kan ufarliggjøres ved å fjerne livsviktige deler av den avbildede kroppen. Særlig er det påkrevet å fjerne hodet. Abu Hurairah, en av Mohammeds følgesvenner, beretter om hva som skjedde da Jibreel (engelen Gabriel) kom til Mohammed: 
Jibreel came to me and said: «I came to you last night and was prevented from entering simply by the fact that there were statues (tamaatheel) at the door, and there was in the house a curtain with pictures (tamaatheel) on it, and there was a dog in the house. So, order that the head of the statue (timthaal) which is in the house be cut off so that it may become like the form of a tree; order that the curtain be cut up and made into two cushions spread out on which people walk; and order that the dog be put out.» The Messenger of Allah (peace and blessings of Allah be upon him) then did so.

Abu Dawud 3/1549, nr. 4146

$\AA$ fjerne en statues hode, som beordret i hadithteksten hos Abu Dawud, underst $\varnothing t t e r$ forestillingen om at symbolsk lemlestelse kan ha tilnærmet samme effekt som reell lemlestelse. Det refereres til en tett sammenheng mellom bildet og avbildet, noe som ytterligere styrker inntrykket av at bildets aktørkvaliteter blir tillagt stor vekt i sunni-islamsk tradisjon (Shakir, 1998, s. 72-73, 209; Al-Qaradawi, 2003 [1969], s. 92-93, 105; Grabar, 2005, s. 43; Gruber, 2009, s. 229, 236). ${ }^{2}$

En rekke hadithtekster oppfordrer betrakteren til aktiv handling i møtet med antropomorfe bilder. I utsnittet nedenfor ligger ordene i munnen til Abu Bakr, fra Mohammeds nære krets:

$$
\begin{aligned}
& {[\ldots] \ll(\text { do not leave) an image (surah) without obliterating/effacing it.» }} \\
& \text { Muslim 2/459, nr. } 2115
\end{aligned}
$$

Hadithteksters oppfordringer om å tilintetgjøre bilder har ført til ulike fortolkninger blant lærde. Krav om fysisk tilintetgjørelse høres særlig i miljøer der fundamentalistiske tolkninger av kildetekstene står sterkt. Grupperinger som markant fordømmer, og aktivt ødelegger antropomorfe bilder, er blant andre wahhabitter, salafister og talibangrupperinger. Mest kjent fra nyere tid er antakelig den allerede nevnte sprengingen av Bamiyan-buddhaene i 2001 (kommentert av Kepel, 2002, s. 233-234; Morgan, 2005, s. 136-138; Flaskerud, 2010, s. 135).

På den annen side mangler det ikke eksempler på at islamske lærde har inntatt mer moderate og pragmatiske synspunkter. Antropomorfe bilder er blitt tatt vare på i mange muslimske samfunn. I Istanbul ble mosaikker av Maria og Jesus bevart under lag av kalk i flere hundre år da kirken Hagia Sofia fikk ny funksjon som moské. I stedet for å velge den mest drastiske løsningen, å ødelegge bildene, kan de altså gjøres uvirksomme dersom de dekkes til.

Ett spesialtilfelle diskuteres inngående når det gjelder risiko for bildedyrkelse og polyteisme. Følgende spørsmål reises og diskuteres blant islamske lærde på grunnlag av motstridende hadithtekster: Kan det gjøres unntak for lek med dukker?

Dukker involverer ofte eieren i et hengivenhetsforhold. Allikevel forsvarer mange lærde dukker som leketøy for små jenter. Konklusjonen om at dukker kan tillates, utledes fra flere hadithtekster som handler om hvordan Mohammeds hustru Aisha får lov til å leke med dukker som liten. Aisha skal ha vært 6 år gammel da hun kom til Profetens hus. Her forteller hun fra sin barndom:

I used to play with dolls in the presence of the Prophet (peace and blessings of Allah be upon him). And I had girl-friends who played along with me. They would hide (feeling shy) from him (peace and blessings of Allah be upon him) whenever he entered. But he (peace and blessings of Allah be upon him) would send for them to join me and they would play with me.

al-Bukhari 8/95, nr. 151, liknende ordlyd hos Muslim 4/1299, nr. 5981 og Abu Dawud 3/1549, nr. 4146 
Det fremgår av teksten at Mohammed ikke har noe i mot dukkene og lekedyrene. Lærde som taler i favør av dukker som leketøy, fremhever at lek med dukker forbereder jenter på den voksne kvinnerollen. Med belegg i kildetekstene velger de dermed å vektlegge mulighetene for sosialisering og opplæring fremfor å betone de betenkelige aspektene ved lek med dukker.

Det er imidlertid hevet over tvil at dukker er i stand til å vekke sterke følelser, og at små jenter ofte utvikler tette relasjoner til sine dukker. En formildende omstendighet i disse tilfellene er at barn er umodne og derfor ikke har de samme religiøse forpliktelser som voksne (Ramadan, 2004 [1999], s. 91).

Det at dukker av mange lærde blir ansett som tillatt og anbefalt leketøy, har oppmuntret dukkeindustrien. Filledukker, slike som Mohammeds hustru Aisha i følge hadithtekster skal ha lekt med, er populære. Det finnes flere produsenter. For eksempel lanserer firmaet Aisha Dolls dukker uten ansiktstrekk (jamfør forestillingen om at bilder nøytraliseres ved å utradere ansiktet). Firmaet Aisha Dolls ledsager markedsføringen av dukkene med juridiske erklæringer fra lærde for å forsikre om at de ikke strider mot islamske idealer. ${ }^{3}$

Det finnes likevel lærde som understreker skadevirkningene ved lek med dukker. De mener barn får inntrykk av at det er akseptert å utvikle nære relasjoner til tredimensjonale antropomorfe bilder. Summen av betenkeligheter har ført til at dette mindretallet av lærde uttrykker motvilje mot å la små jenter eie dukker (Shakir, 1998, s. 82).

Hvordan bilders plassering og bruk påvirker omgivelsene, er et annet tema som opptar islamske lærde. Det er verdt å merke seg forhenget som ble omgjort til puter i den tidligere siterte hadithteksten fra Abu Dawud. Denne og liknende formuleringer i andre hadithtekster har ledet til oppfatninger om at et bildes posisjon er avgjørende for dets virkning på betraktere. Dersom bildet får en fremtredende plass, vekker det lettere positive følelser, som beundring. Spesielt er det viktig at bildet aldri plasseres i bønneretningen, siden en slik plassering gir inntrykk av at den bedende henvender seg til bildet. Dersom bildet derimot blir plassert lavt, og brukt til å sitte på (pute) eller trå på (teppe) mister det sin forførende kraft fordi betrakterne ved sine handlinger demonstrerer at de ringeakter avbildningen. Enkelte lærde hevder at dersom antropomorfe bilder behandles nedlatende, kan deres tilstedeværelse tolereres (Al-Qaradawi, 2003 [1960], s. 92, 93, 105). ${ }^{4}$

\title{
2. Distraksjon av sansene
}

Risiko for bildedyrkelse og polyteisme har vist seg å være tett forbundet med antropomorfe bilder. I dette avsnittet utdypes islamske lærdes meninger om en annen effekt av figurative bilders nærvær, nemlig bildenes distraherende virkning. I denne sammenheng er alle typer av figurative bilder aktuelle, fra de med antropomorfe motiver til de med landskapsmotiver.

I hadithlitteraturen fortelles det om hvordan Mohammed ble distrahert av figurative bilder som var plassert i rommet der han skulle be:

\begin{abstract}
Aisha (may Allah be pleased with her) had a curtain (having images on it) and she screened the side of her house with it. The Prophet (peace and blessings of Allah be upon him) said to her, «Remove it from my sight, for its images are still coming to my mind (and distracting me) in my prayers.»
\end{abstract}

al-Bukhari 7/544, nr. 842, liknende ordlyd hos Muslim 3/1158, nr. 5255

Med utgangspunkt i hadithtekster som denne, advarer lærde mot figurative bilders distraherende virkning på betraktere. Det er bred enighet blant lærde om at figurative bilder $\varnothing v e r$ særlig uheldig innflytelse på steder der bønn praktiseres. Bønnerommene i de fleste moskéer er derfor frie for figurativ dekor og figurative bilder. Men i islam trekkes det ikke noe prinsipielt skille mellom et lokale som er innrettet for religiøs praksis, som en moské, og en hvilken som helst annen lokalitet. Hellig og verdslig rom glir over i hverandre: En bedende 
muslim gjør et hvilket som helst rom til hellig ved å bre ut et bønneteppe (Grabar, 2006, s. 105; Ramadan, 2004 [1999], s. 173; Naguib, 2001, s. 50, 60; Werbner, 2002, s. 115).

Religionens uavklarte stilling i hverdagens fysiske miljøer har ført til at lærde er uenige om $i$ hvilke kontekster figurative bilder bør unngås. Av praktiske årsaker ber mange muslimer i hjemmet. I hadithlitteraturen berettes det at Guds engler viker unna hus der det finnes figurative bilder. Fortellingene finnes i flere varianter, som ligger tett opp til hverandre, i samlingene til Muslim og al-Bukhari. Samlet sett har fortellingene dermed gjennomslagskraft, både fordi de gjengis i de mest ansette samlingene, og fordi de opptrer i flere fortellerkjeder. I ett av tekststedene hos Muslim lyder profeten Mohammeds formaning slik:

Angels do not enter a house (or any other place) where there are statues (tamaatheel) or pictures (tasawir).

Muslim 3/1162, nr. 5276

Her er oppfordringen om å unngå figurative bilder klar. Guds velsignelse og tilstedeværelsen av bilder synes å utelukke hverandre, slik at huseiere blir henstilt om å velge det ene eller det andre alternativet. Slike hadithtekster danner grunnlaget for argumentene til lærde som hevder at figurative bilder bør unngås overalt, ikke bare i moskéen, men også i hjemmene.

Det hersker likevel ikke enighet blant lærde om en så absolutt holdning. I hadithlitteraturen beskrives det også at profeten Mohammed hadde et eget sted i hjemmet for bønn. Enkelte lærde mener at det vil være mulig å dedikere et sted i hjemmet til bønn, og å skjerme dette stedet fra forstyrrende visuelle impulser (McCloud, 1996, s. 69-70; Werbner, 2002, s. 115; Schimmel, 1994, s. 49). Den nødvendige ro og konsentrasjon kan oppnås ved å dekke til bilder og holde dem borte fra bønneretningen. Begge de nevnte posisjoner bygger på grunnidéen om at det ikke finnes prinsipiell forskjell på hellig og verdslig rom, men i det siste tilfellet fremholder altså lærde at det er religiøst forsvarlig å innrette dagliglivets steder etter ulike aktiviteter, og å vie dem til bestemte formål enten på temporær eller permanent basis.

Bekymringene for distraksjon av sansene springer ut fra forestillingen om at figurative bilder forstyrrer den religiøse konsentrasjonen, som er en nødvendig forutsetning for bønn. Selv om det sjelden utdypes $h v a$ distraksjonene består i, kommer det frem i argumentasjonene at det er opplevelsesaspektet ved figurative bilder som vurderes negativt. Synsinntrykket av gjenkjennelige former setter i gang assosiasjonsspill, bildene inspirerer til meddiktning, utfordrer betrakterens fantasi og krever for mye oppmerksomhet.

Både når det gjelder risiko for bildedyrkelse og når det gjelder distraksjon av sansene, advares det mot at betrakterens engasjement i bildene kan representere et første steg på veien mot polyteisme, det å spre tilbedelse i flere retninger og mot flere mål (shirk). ${ }^{5}$ Generelt er islamske lærde på vakt mot alle typer av figurative bilder, uansett kontekst, dersom bildene inviterer til engasjement, beundring eller hengivenhet.

\section{Imitasjon av det guddommelig skapte}

I motsetning til de to foregående innvendingene, som retter seg mot betraktere og brukere av figurative bilder, retter denne innvendingen seg først og fremst mot dem som fremstiller bilder. Figurativ fremstilling oppfattes som fors $\varnothing \mathrm{k}$ på å imitere Guds skaperverk, og som forsøk på å måle seg med Gud i skaperkraft (Koranen, 59.24, 3.42-43, 5.110).

Hadithlitteraturen har bemerkelsesverdig mange tekster som beskriver konsekvensene av bildefremstilleres aktiviteter. På oppgjørets dag blir de som fremstiller bilder, satt på en avgjørende prøve idet de tvinges til å fors $\varnothing \mathrm{ke}$ a puste liv inn i sine figurer. Ibn Abbas, Mohammeds nære slektning og forbundsfelle, forteller en bildefremstiller hva som venter ham: 
[.... Then Ibn Abbas (may Allah be pleased with him and his father) said: «I heard Allah's Messenger (peace and blessings of Allah be upon him) saying: «Whoever makes an image (surah) in this world would be compelled to breathe soul (rooh) in it on the Day of Resurrection, but he will never be able to do so.»

Muslim 3/1162, nr. 5273, liknende ordlyd hos al-Bukhari 7/541, nr. 835, al-Bukhari 7/547, nr. 846, Muslim 3/1160, nr. 5268

Det vil selvsagt ikke være mulig for bildefremstilleren å gi liv til sine figurer. Men ikke alt i skaperverket har liv, og en annen hadithtekst differensierer saken ved å sortere bildemotiver etter forskjellige alvorlighetsgrader. Ibn Abbas gir råd til en mann som fremstiller bilder:

A man came to Ibn Abbas (may Allah be pleased with him and his father) and said: «I am a person that make these images (suwar); give me a religious verdict (fatwa) about them.» [.... Ibn Abbas (may Allah be pleased with him and his father) said: «If you must do it (i.e. make these images) then make (images of) trees and lifeless things ('ash-shajarah wa maa laa nafs lahu).»

Muslim 3/1161, nr. 5272

En hoveddistinksjon når det gjelder motiver, går mellom det besjelede og det ubesjelede $\mathrm{i}$ skaperverket (det som har, eller ikke har, ruh). Ibn Abbas' siste replikk i denne tekstpassasjen antyder at avbildninger av trær og livløse ting kan forsvares. De fleste lærde er enige om at begrepet «ubesjelet» dekker visse deler av Guds skaperverk, som planter, mineraler, vann, himmellegemer, og, i tillegg, menneskelagede gjenstander.

Et mindretall av lærde mener likevel at planter faller inn under imitasjonsrestriksjonene. De bygger da på hadithtekster der dyr og planter sidestilles når det gjelder avbildning (for eksempel Muslim 3/1162, nr. 5275 og al-Bukhari 7/541, nr. 1685, gjengitt hos Shakir, 1998). Vektlegging av disse tekstene har ført til at dette mindretallet av lærde fraråder all imitasjon av skaperverket, uten at det trekkes noe prinsipielt skille mellom mennesker, dyr og planter. Det er allikevel bred enighet blant lærde om at bilder av menneskelagede gjenstander som biler, båter og maskiner er uproblematiske (Shakir, 1998, s. 9-10; Al-Qaradawi, 2003 [1960], s. 95).

Lærde er uenige om hva imitasjonsrestriksjonene innbefatter, men for $\varnothing v$ vig råder det ingen tvil om at hadithtekstene lover strenge straffer for dem som ikke respekterer restriksjonene.

Hadithtekster som tar opp problemstillinger rundt imitasjon av skaperverket er mange, og de er tungtveiende idet flere av dem er hentet fra de mest ansette samlingene, og idet de på viktige punkter er samstemte. Derfor trekkes slutningen om at figurativ fremstilling av liv, særlig det besjelede og bevegelige liv, bør unngås. Dette berører i særdeleshet fremstilling av menneskeskikkelsen, som udiskutabelt innbefattes av imitasjonsrestriksjonene. Lærde som er tilknyttet de tradisjonssterke sunnittiske lovskolene Hanafi, Maliki, Shafi og Hanbali, er i stor grad samstemte når det gjelder å forby fremstilling av mennesker i maleri og skulptur (Vernoit, 2006, s. 19; Shakir, 1998, s. 10; Ramadan, 2004 [1999], s. 237).

\section{Reduksjon av det guddommelige og det høyverdige}

Den fjerde og siste innvendingen mot figurativ fremstilling er spesifikk, og rettes særlig mot fors $\varnothing \mathrm{k}$ på å avbilde Gud. Siden Gud oppfattes som enhetlig og samtidig altomfattende (tawhid), er Gud umulig å forestille seg. Dermed er det også umulig å gjøre Gud synlig i et bilde, fordi et bilde ville redusere det guddommelige til en fattbar størrelse.

Forbudet mot avbildning av Gud utvides ofte til å omfatte engler og profeter, og i særdeleshet profeten Mohammed. Men avbildning av Mohammed reiser helt andre problemstillinger enn avbildning av Gud: Siden Mohammed er en historisk person, som har 
hatt et utseende, skulle det i prinsippet være mulig å fremstille ham visuelt. I teologiske og filosofiske skrifter blir Mohammed betegnet som en dualistisk natur, som både har de ypperste menneskelige egenskaper og transcendente kvaliteter. Videre blir Mohammed sett opp til som den perfekte utgaven av mennesket (insan al-kamil), og han æres spesielt fordi han var en forutsetning for at islam ble kjent (Ahmed, 2004 [1992], s. 169-170; Werbner, 2002, s. 115, 132, 133; Schimmel, 1994, s. 245-246; Nicholson, 1978 [1921], s. 77-89). Det figurative bildet ansees ikke å være noe medium som egner seg for å formidle Mohammeds store spekter av usynlige kvaliteter (om portrettering av Mohammed gjennom historien, se Gruber, 2009, s. 229-263; Grabar og Natif, 2004, s. 33-34).

Denne fjerde innvendingen mot figurative bilder begrunnes vanligvis ikke ut fra hadithtekster, men er en naturlig konsekvens av samspillet mellom de tre tidligere nevnte innvendingene: For det første ville figurative fremstillinger av Gud og hans utvalgte budbringere kunne invitere til dyrkelse av selve bildet, og dermed resultere i polyteisme. For det andre ville bildene alltid måtte være usanne siden Gud ikke lar seg visualisere, og siden ansiktstrekkene til engler og profeter er ukjente. Slik sett fører figurative bilder ikke bare til uønsket distraksjon, men villeder troende, som tvert i mot oppfordres til å fokusere på hva Gud, og hans utvalgte, representerer på et idéplan. For det tredje ansees imitasjon av det besjelede skaperverket som en klanderverdig handling, og fors $\varnothing \mathrm{k}$ på avbildning av Mohammed kommer helt klart inn under imitasjonsrestriksjonene. Fremstillere av Mohammed-bilder ansees å stå ansvarlige for bildenes negative virkninger når de gir betraktere forslag i visuell form på kvaliteter som bør forbli usette.

I lys av disse betraktningene var publiseringen av Mohammed-tegningene i 2005 ikke bare en reduksjon av det høyverdige, de berørte på det dypeste flere av kjernespørsmålene knyttet til figurativ fremstilling i islam.

\section{Sunni-islamsk tradisjon utfordres av moderne fremstillingsteknikker}

Da fotografiets utbredelse begynte å merkes mot slutten av 1800-tallet, oppsto en ny situasjon som bød på utfordringer for den eksegetiske praksis. Fotografiets karakteristika slo ut på overraskende måter i forhold til de fire hovedinnvendingene mot figurasjon. Mediets særegenhet som avbildningsteknikk har vært gjenstand for lærdes intense oppmerksomhet. $\AA$ imitere et synsinntrykk $\mathrm{i}$ en håndverksteknikk impliserer en tolkningsfase og en lengre fremstillingsfase, mens fotografering ansees som et $\emptyset$ yeblikks registrering av det som allerede befinner seg foran linsen.

Egyptiske Mohammed Bakhit al-Mut'i, kjent juridisk rådgiver (mufti) i religiøse spørsmål, formulerte sin aksept for fotografiet på denne måten: A fotografere er ikke annet enn å fange en refleksjon med en spesiell teknikk. Bakhit presiserte at de religiøse restriksjonene er rettet mot fors $\emptyset \mathrm{k}$ på å imitere Guds skaperverk, mens fotografering kan sammenliknes med det å fryse fast et speilbilde. Siden det ikke er forbudt å betrakte Guds skaperverk i et speil, kan det heller ikke være forbudt å fotografere. ${ }^{6}$

Noen grupperinger av lærde vurderer fotografiet på andre premisser og trekker andre slutninger enn Bakhit. Et par argumenter skal kort nevnes. I hadithtekstene der det advares mot å imitere skaperverket, benyttes ofte begrepet surah om bilder. Begrepet surah betegner også fotografi i arabiske språkområder i dag. Det faktum at samme begrep favner flere bildegenrer, har ledet enkelte lærde til den konklusjon at fotografi bør forbys. Standpunktet er omstridt siden fotografi som teknikk ikke var kjent på den tiden hadithtekstene ble nedskrevet (Ramadan, 2004 [1999], s. 237-238, 245).

Et annet argument mot fotografiet kommer fra lærde som legger større vekt på bildets virkninger enn på bildets fremstillingsteknikk. De påpeker at et speilbilde og et fotografi er vesensforskjellig i og med at speilbildet er flyktig, mens fotografiet er permanent trykket på et underlag. Det betyr at fotografiet vil være vedvarende til stede som påvirkningsfaktor. Lærde 
som hevder dette synspunktet, understreker at fotografiet har liknende virkning som andre figurative bilder når det gjelder responsmønstre som bildedyrkelse og distraksjon av sansene. Fotografiet er blitt så rimelig at alle kan skaffe seg det. Uten strenge restriksjoner vil det kunne skje en massespredning av figurative bilder med negativ innflytelse. Denne grupperingen av lærde taler derfor for at fotografiet per definisjon bør være forbudt. ${ }^{7}$

I det store og hele har idéen om at fotografiet er tillatt fordi det registrerer snarere enn imiterer, hatt stor gjennomslagskraft blant islamske lærde. I dag diskuteres først og fremst fotografiets bruksområder: I hvilke tilfeller er bruk av fotografi tilrådelig, betenkelig eller forbudt? Blant lærde finnes ulike svar på disse spørsmålene. Mange innser at det ville være utenkelig å skjerme samfunnet for den globale utviklingen der bruk av moderne kommunikasjonsmedier griper om seg. Dessuten gjelder det å kunne dra nytte av mulighetene moderne medier tilbyr. Derfor aksepterer de fleste lærde bruk av figurativ fremstilling i fotografisk form i forbindelse med forskning, utdanning, kunnskapstilegnelse og spredning av informasjon. I de tilfellene der fotografiet appellerer til betrakterens følelser, maner mange lærde til varsomhet. Fotografier av fremstående personer, for eksempel av ledere eller helter, bør ifølge flere lærde ikke henges opp. Å gi slike bilder en fremtredende plass kan inspirere til følelser som har valør av tilbedelse. ${ }^{8}$

Det er ikke uvanlig at lærde trekker en grense mellom bruk av fotografi som hjelpemiddel i samfunnsgagnlig arbeid og som kilde til privat hygge. Den naturlige konsekvensen av et slikt standpunkt er at fotografier i hjemmemiljøet frarådes (Ramadan, 2004 [1999], s. 236-237). ${ }^{9}$

Forholdet mellom fotografiske stillbilder og levende bilder, som fjernsyn, film, video og dataanimasjon, er også utredet av islamske lærde. Noen ser med mildere øyne på levende bilder enn på stillbilder fordi levende bilder ikke er bestandige. Siden levende bilder ikke representerer noen vedvarende tilstedeværelse, er risikoen for uheldig innflytelse redusert. Andre lærde trekker ikke prinsipielle skillelinjer mellom stillbilder og levende bilder. I dette siste tilfellet gjelder samme retningslinjer for begge bildekategoriene, altså at tillatelse avhenger av bildenes art og anvendelse. ${ }^{10}$

Bildemedienes ferskeste muligheter synes ikke å være tilstrekkelig utredet av lærde ennå. For eksempel er det vanskelig å finne uttrykte synspunkter på hvordan overbevisende bildemanipulasjon med digitale medier forholder seg til imitasjon eller registrering av skaperverket.

\section{Konkluderende bemerkninger}

Gjennomgangen av argumentasjonen på taswir-feltet har vist at islamske lærde finner belegg i kildene for ulike posisjoneringer med hensyn til figurativ fremstilling. Det finnes ingen konsensus blant lærde når det gjelder hvilke kontekster, hvilke motiver og hvilke fremstillingsteknikker som tillates. Få taler for et absolutt forbud, men nær sagt alle er opptatt av å begrense og kontrollere det figurative bildets virkninger på betraktere og brukere. Gjennomgangen av argumentasjonen har videre vist at fremstilling av menneskeskikkelsen er blant de mest kontroversielle og følsomme temaene i sunni-islamsk visuell tradisjon.

Når islamske lærde diskuterer figurativ fremstilling, bidrar de til å forme religiøse normer på feltet. Praktiserende muslimer ønsker å holde seg til religiøse normer, men de vil måtte velge hvilke fortolkningsmiljøer de lytter til. Ytterligere en utfordring ligger i å balansere sunni-islamsk tradisjon mot vestlig figurasjons-orientert tradisjon som gjennom nyere medier har fått en fremtredende stilling innen visuell kommunikasjon.

Det var nettopp disse krevende avveiningene som opptok unge norske muslimer da de samtalte med meg på videregående skoler i Oslo for et par år siden. Ungdommene er aktive i arbeidet med å meisle ut moderne muslimske identiteter. Religionen står sentralt i livet deres og oppfattes som et personlig anliggende: Slik sett er ungdommene eksponenter for religiøs 
«revival» i moderne tid. Men de har ulike måter å takle utfordringene på. Noen orienterer seg i mangfoldet av autoritative tolkninger i islam for å finne frem til et ståsted som gjør det mulig å forene religiøse og sekulære livsdimensjoner. Andre søker i retning av en universell form for islam, renskåret og renset for kulturelle tilføyelser. Det siste alternativet representerer den idéen om umma som ofte målbæres blant nyfundamentalister og radikaliserte. Nyere forskning har vist at de unge norske muslimenes valg av løsninger føyer seg inn i internasjonale tendenser (Jacobsen, 2002; Jacobsen, 2006; Prieur, 2004, s. 158-159; Jacobson, 1998, s. 32; Clarke, 1998, s. 3, 16; Schmidt, 2007, s. 31-37; Larsson, 2011, s. 153; Jensen, 2003, s. 39).

På dette punkt vil jeg foreta en tvist i perspektivet og argumentere for at de unge muslimenes erfaringer med krysspress er relevante for flere enn dem selv. Ungdommene står midt $\mathrm{i}$ de daglige utfordringene $\mathrm{i}$ prosessen med å samordne kunnskap fra flere tradisjoner som løper sammen i deres liv. Det som er spesielt ved deres situasjon, er at de får sterke, og til dels motstridende, påvirkningskrefter tett på seg allerede i tidlig barndom. Det som derimot er typisk og moderne ved deres situasjon, er at de hanskes med mangfold og motsetninger.

Vi befinner oss alle i den samme multikulturelle og uoversiktlige virkeligheten, og vi må håndtere nettopp mangfold og motsetninger dersom vi ønsker å kommunisere visuelt til et publikum med sammensatt og uensartet kunnskapsbakgrunn. Vi trenger derfor å minnes om at det figurative bildet har vært, og er, et omstridt uttrykk innenfor flere tradisjoner.

Allerede $\mathrm{i}$ artikkelens åpningsavsnitt antydet jeg mitt eget ståsted når det gjelder samtidens utfordringer: Jeg har tro på at $\emptyset \mathrm{kt}$ bevissthet om ulike virkelighetsforståelser vil utgjøre et fortrinn i samtidens og fremtidens visuelle kommunikasjonssituasjon.

Kommunikasjonsdeltakere vil alltid veksle mellom å innta avsender- og betrakterrollene. Derfor hviler ansvaret for å kommunisere på begge parter. Men det er ikke til å komme utenom at avsenderen er den initiativtagende part - den som «setter stemningen». Det er derfor mulig å argumentere for at avsenderrollen innebærer et særskilt ansvar, samtidig som den er ytringsfrihetens viktigste posisjon.

Et konstruktivt mål for å bedre kommunikasjonen vil etter min mening være å gjenvinne en viss forutsigbarhet. Det betyr at de som tar rollene som avsendere bør være innforstått med at visuelle budskaps formgivning vekker vel så sterke følelser som budskaps innhold. Avsendere bør fortløpende tenke over hvordan visuelle budskap kan formgis slik at de best mulig kommuniserer etter intensjonen, og slik at risikoen for utilsiktede provokasjoner og misforståelser reduseres. Målet om forutsigbarhet kan avsendere nærme seg ved å utvide kunnskapsforrådet slik at vurderingsevnen får et bredere grunnlag å virke ut fra. $\AA$ ha kunnskap til å beregne et variert publikums respons er et gode som avsenderen disponerer uavhengig av retten til ytringsfrihet, men det er ikke usannsynlig at slik kunnskap også vil få konsekvenser for hvordan ytringsfriheten blir praktisert.

\section{Fremtidig forskning}

Jeg arbeider med skisser til flere artikler der jeg vil kaste kritiske og analyserende blikk på bestemte kommunikasjonssituasjoner. Aktuelle temaer er for eksempel de varierte muslimske reaksjonene på publiseringene av Mohammed-karikaturene i 2005. Karikaturene er blitt analysert i lys av storpolitisk spill og ytringsfrihet, men lite drøftet i lys av visuelle kunnskapstradisjoner. Jeg ønsker å løfte frem unge muslimers stemmer, og drøfte karikaturenes konsekvenser i norske, multikulturelle lokalmiljøer.

Et annet tema jeg vil se nærmere på, er hvilke virkemidler fundamentalistiske sunnimuslimer bruker i visuell propaganda: I hvilken grad følger de sine egne retningslinjer? I hvilken grad justerer de seg mot sammensatte betraktergrupper? På hvilke måter balanserer de hensynet til egen overbevisning og hensynet til budskapets rekkevidde? Dette er problemstillinger i tiden, ikke bare $\mathrm{i}$ forbindelse med den offensive og svært synlige 
grupperingen IS, men like mye i forbindelse med de mange salafi-inspirerte nettstedene som henvender seg til muslimer i diaspora.

I en slik utvidet kontekst vil denne første artikkelen danne en nødvendig plattform som jeg kan vise tilbake til under drøftingene.

\section{Birte Brekketo}

Førsteamanuensis, PhD

Fakultet for teknologi, kunst og design

Høgskolen i Oslo og Akershus

E-post: Birte.Brekketo@hioa.no 


\section{Litteratur}

Ahmed, A. S. (2004 [1992]). Postmodernism and Islam: Predicament and Promise. London og New York: Routledge

Al-Qaradawi, Y. (2003 [1960]). The Lawful and the Prohibited in Islam. Houston Texas: Elfarouq Foundation

Alhassan, A. (2008). The Twelve Cartoons. I E. Eide, R. Kunelius og A. Phillips (red.), Transnational Media Events: The Mohammed Cartoons and the Imagined Clash of Civilizations (s. 39-59). Göteborg: Nordicom

Ammerman, N. T. (2007). Introduction: Observing Modern Religious Lives. I N. T. Ammerman (red.), Everyday Religion: Observing Modern Religious Lives, (s. 3-19). Oxford og New York: Oxford University Press

Anderson, B. (1992 [1983]). Imagined Communities. London: Verso

Berger, P. L. (2007). Foreword. I N. T. Ammerman (red.), Everyday Religion: Observing Modern Religious Lives, (s. v-viii). Oxford og New York: Oxford University Press

Brekketo, B. (2013). Taswir i norsk kontekst: En unders $\phi$ kelse av hvordan unge norskpakistanske muslimer forholder seg til visuell kommunikasjon med figurative uttrykk. Universitetet i Bergen, Institutt for arkeologi, historie, kultur- og religionsvitenskap: Avhandling for PhD-graden

Clarke, P. B. (1998). Islam in Western Europe: Present State and Future Trends. I P. B. Clarke (red.), New Trends and Developments in the World of Islam (s. 3-41). London: Luzac Oriental

Doi, A. R. I. (1989). «Sunnism» I S. Hossein Nasr (red.), Islamic Spirituality: Foundations (s. 147-160). London: SCM Press Ltd

Flaskerud, I. (2010). Bildebruk og bildestrid i islam. Dīn. Tidsskrift for religion og kultur, 3-4, s. $117-139$

Goldziher, I. (1981 [1910]). Introduction to Islamic Theology and Law. New Jersey: Princeton University Press

Grabar, O. (2005). Early Islamic Art, 650-1100: Constructing the Study of Islamic Art. Hampshire: Ashgate Publishing Company

Grabar, O. (2006). Islamic Art and Beyond. Hampshire: Ashgate Publishing Company

Grabar, O. og N. Mika. (2003). The Story of the Prophet Mohammed, Studia Islamica, 96, s. 19-38

Gruber, C. (2009). Between Logos (Kalima) and Light (Nür): Representations of the Prophet Mohammed in Islamic Painting. Muqarnas: An Annual on the Visual Cultures of the Islamic World, (26, s. 229-263). Leiden og Boston: Brill

Halldén, P. (2006). Militant Salafism on the Internet: Alneda.com' and the Legacy of Yusuf al-'Ayyiri. I G. Larsson (red.), Religious Communities on the Internet (s. 62-86). Uppsala: Universitetstryckeriet

Hervik, P. (2008). Original Spin and Its Side Effects. Freedom of Speech as Danish News Management. I E. Eide, R. Kunelius og A. Phillips (red.), Transnational Media 
Events: The Mohammed Cartoons and the Imagined Clash of Civilizations (s. 59-81). Göteborg: Nordicom

Hodgson, G. S. (1964). Islam and the Image. History of Religions, 3, 2, s. 220-260

Jacobsen, C. M. (2002). Tilhørighetens mange former: Unge muslimer i Norge. Oslo: Pax Forlag

Jacobsen, C. M. (2006). Staying on the Straight Path: Religious Identities and Practices among Young Muslims in Norway. Universitetet i Bergen, Institutt for sosialantropologi: Avhandling for PhD-graden

Jacobson, J. (1998). Islam in Transition: Religion and Identity among British Pakistani Youth. London and New York: Routledge

Jensen, T. (2003). Mange muslimer, mange islamer. I M. Sheikh, F. Alev, B. Baig og N. Malik (red.), Islam i bevagelse (s. 23-65). Danmark: Akademisk Forlag

Kepel, G. (2002). Jihad: The Trail of Political Islam. London og New York: I. B. Tauris Publishers

Klausen, J. (2009). The Cartoons that Shook the World. New Haven og London: Yale University Press

Koranen. (1996 [1989]). Norsk-arabisk utgave tilrettelagt i oversettelse av Einar Berg. Oslo: Universitetsforlaget

Kühle, L. (2012). Excuse me, which radical organization are you member of? Reflections on methods to study highly religious but non-organized Muslims. I N. Jeldtoft og J. S. Nielsen (red.), Methods and Contexts in the Study of Muslim Minorities: Visible and Invisible Muslims (s. 77-92). New York: Routledge

Larsson, G. (2009). Muslimer och islam. I D. Andersson og Å. Sander (red.), Det mångreligiösa Sverige - ett landskap i förändring s. 463-521). Lund: Studentlitteratur

Larsson, G. (2011). Muslims and the New Media: Historical and Contemporary Debates. Farnham: Ashgate

Levitt, P. (2007). Redifining the Boundaries of Belonging: The Transnationalization of Religious Life. I N. T. Ammerman (red.), Everyday Religion: Observing Modern Religious Lives (s. 103-121). Oxford og New York: Oxford University Press

McCloud, A. B. (1996). This Is a Muslim Home: Signs of Difference in the African-American Row House. I: B. D. Metcalf (red.), Making Muslim Space in North America and Europe (s. 65- 74). Berkeley, Los Angeles og London: University of California Press

McGuire, M. B. (2008). Lived Religion: Faith and Practice in Everyday Life. Oxford og New York: Oxford University Press

Metcalf, B. D. (1982). Islamic Revival in British India: Deoband, 1860-1900. New Jersey: Princeton University Press

Mirza, Y. (2005). Abraham as an Iconoclast: Understanding the Destruction of «Images» through Qur'anic Exegesis, Islam and Christian-Muslim Relations, 16, 4, s. 413-428

Morgan, D. (2005). The Sacred Gaze: Religious Visual Culture in Theory and Practice. Berkeley, Los Angeles og London: University of California Press

Naguib, S. A. (2001). Mosques in Norway: The Creation and Iconography of Sacred Space. Oslo: Novus forlag 
Nasr, S. H. (1989). God. I S. H. Nasr (red.), Islamic Spirituality: Foundations (s. 311-324). London: SCM Press Ltd

Nicholson, R. A. (1978 [1921]). Studies in Islamic Mysticism. Cambridge, London, New York og Melbourne: Cambridge University Press

Prieur, A. (2004). Balansekunstnere: Betydningen av innvandrerbakgrunn i Norge. Oslo: Pax Forlag A/S

Ramadan, T. (2004 [1999]). At vare europaisk muslim: Islamske kilder i en europaisk sammenheng. København: Forlaget Hovedland

Roald, A. S. (2004). Islam. Oslo: Pax Forlag A/S

Roy, O. (2004). Globalized Islam: The Search for a New Ummah. New York: Columbia University Press

Roy, O. (2007). Secularism Confronts Islam. New York: Columbia University Press

Sanyal, U. (1996). Devotional Islam and Politics in British India: Ahmad Riza Khan Barelwi and his Movement, 1870-1920. Delhi: Oxford University Press

Schacht, J. (1979 [1950]). The Origins of Mohammedan Jurisprudence. Oxford: Oxford University Press

Schimmel, A. (1994). Deciphering the Signs of God: A Phenomenological Approach to Islam. New York: State University of New York Press

Schmidt, G. (2007). Muslim i Danmark-muslim i verden: En analyse af muslimske ungdomsforeninger og muslimsk identitet i årene op til Muhammad-krisen. Uppsala: Universitetstryckeriet

Shakir, A. M. A. R. (1998). The Islamic Ruling Concerning At-Tasweer. Philadelphia: Zakee Muwwakkil's Books \& Articles

Vernoit, S. (2006). The Visual Arts in Nineteenth-Century Muslim Thought. I D. BehrensAbouseif og S. Vernoit (red.), Islamic Art in the 19th Century: Tradition, Innovation and Eclecticism (s. 19-37). Leiden/Boston: Brill

Vikør, K. S. (2003). Mellom Gud og stat: Ei historie om islamsk lov og rettsvesen. Oslo: Spartacus

Vogt, K. (2005). Islam - tradisjon, fundamentalisme og reform. Oslo: J. W. Cappelens forlag AS

Vogt, K. (2007). Hva er Islam. Oslo: Universitetsforlaget

Werbner, P. (2002). Imagined Diasporas among Manchester Muslims. Oxford og Santa Fe: World Anthropology

\section{Sunni-muslimske nettsteder}

IslamiCity Forum: Nettstedet refererer til Mohammed S. Al-Munajjid, og er salafi-orientert: Om at fotografi er forbudt, og at bilder leder til shirk; Hentet 26.08.2014 fra http://www.islamicity.com/forum/forum_posts.asp?TID=5048\&PN=8.

Islamic Network: Nettstedets mål er å spre kunnskap om, og forståelse for, islam som religion. Nettstedet er salafi-orientert: Om at TV ikke er tillatt; Hentet 09.04.2014 fra http://www.islaam.net/display/display.php?category=20\&id=177. 
Islam Online: Nettsted opprettet i 1997 for å bistå muslimske minoriteter i vestlige samfunn. Henvisningene som brukes i artikkelen, er fra tiden da Yusuf Al-Qaradawi satt i redaksjonen (1997-2010). Nettstedet ble i 2010 omstrukturert og har i dag en mer konservativ profil. Det er derfor vanskelig å finne frem til de oppgitte henvisningene, som er hentet fra det tidligere nettstedets tjeneste «Living Shari'ah >Ask the Scholar» og «Fatwa Bank»: Fatwa on Photography, fatwa utstedt 16.09.2003, Hanging Pictures on Walls, fatwa utstedt 05.07.2003, Fatwa on Pictures on Clothes, fatwa utstedt 16.09.2002. Alle innleggene foreligger i utskrift, og er hentet 26.02.2009 fra http://www.islamonline.net.

Islam.no: Norsk nettsted i regi av Den islamske informasjonsforeningen. Ansvarlig redaktør er Basim Ghozlan. Henvisningene i teksten er hentet fra tjenesten «Spørsmål og svar»: Bilder 11.02.2004, Billedforbud i islam? 06.09.2003; Hentet 26.08.2014 fra http://www.islam.no.

Islam QA, Question \& Answer: Nettsted redigert av den lærde Mohammed S. Al-Munajjid. Nettstedet har salafi-profil, og henvender seg til et internasjonalt publikum via forskjellige språk:

Om at fotografiet som medium er forbudt. Hentet 09.04.2014 fra http://www.islamqa.com/index.php?ref=82366\&ln=eng\&txt=photo

Om at bilder på mobil, data og video kan godtas fordi de ikke er bestandige; Hentet 09.04.2014 fra http://www.islamqa.com/index.php?ref=91356\&ln=eng\&txt=photo; http://www.islamqa.com/index.php?ref=88180\&ln=eng\&txt=photo

Om at bilder kan lede til shirk; Hentet 09.04.2014 fra http://www.islamqa.com/index.php?ref=26841\&ln=eng\&txt=photo

Om at bilder for hygge er forbudt, mens nyttige bilder er tillatt; Hentet 09.04.2014 fra http://www.islamqa.com/index.php?ref=88180\&ln=eng\&txt=photo

Om at bilder ikke er tillatt for å minnes avdøde; Hentet 09.04.2014 fra http://www.islamqa.com/index.php?ref=91356\&ln=eng\&txt=photo; http://www.islamqa.com/index.php?ref=91356\&ln=eng\&txt=photo

Om at dukker bør være laget av ull, og ikke ha ansikter; Hentet 09.04.2014 fra http://www.islamqa.com/index.php?ref=9473\&In=eng

Per 26.08.2014 er nettstedet omstrukturert, søkeord: Photo

Our Dialogue, Islam in Perspective: Nettsted styrt av Arab News i Jeddah. Nettstedet oppgir å ha et islamsk perspektiv på spørsmål som opptar samtiden. Det oppgis ikke hvilke lærde det refereres til, men nettstedet gir uttrykk for moderate synspunkter:

Om hvorfor fotografiet er tillatt; Hentet 26.08.2014 fra http://www.ourdialogue.com/answers/articles.php?action=show\&showarticle=1129.

Om at fotografiet defineres som registrering; Hentet 26.08.2014 fra http://www.ourdialogue.com/answers/articles.php?action=show\&showarticle $=1130$

Om at dataspill er tillatt dersom tema og motiver ikke er upassende; Hentet 26.08.2014 fra http://www.ourdialogue.com/answers/articles.php?action=show\&showarticle=139

Sunnah Online: Nettstedet refererer til lærde som ibn-Baz, Al-Albani, Ibn Abd al-Wahhab og Ibn 'Uthaymin. Henvisningene leder til hovedsiden, derfra søkes etter begrepet taswir: Om viktigheten av bildets posisjon; Hentet 26.08.2014 fra http://www.sunnahonline.com/ilm/sunnah/0001.htm 
The Qur'an and Sunnah Society: Nettstedet refererer til Al-Albani: Om at bilder ikke må ha ansikter; Hentet 28.08.2014 fra http://www.qss.org/questions/data/Fundamentals_Haraam.html

Ummah Forum: Nettstedet refererer til lærde som Al-Albani, Al-Qaradawi, Mohammed Qaylish og Faraz Rabbani: Om at fotografi er forbudt, og om at bilder forbindes med shirk; Hentet 26.08.2014 fra http://www.ummah.net/forum/showthread.php?t=31303

World of Islam: Nettsted for konvertitten Tara bint Curtis Gregory. Under «Islamic Articles > Tasweer» gjengis Ibn Baz' fatwa om taswir. Ibn Baz var stormufti i Saudi-Arabia fra 1993 til 1999; Hentet 26.08.2014 fra http://islamicarticles.wordpress.com/tasweer/

\section{Sunni-muslimsk leketøy på nettet}

Aisha Dolls: Nettsted for islamske dukker; Hentet 26.08.2014 fra http://aishadolls.com/

Simply Islam: Nettsted for islamske dukker; Hentet 26.08.2014 fra http://www.simplyislam.com/iteminfo.asp?item $=55030$

Sweetness \& Light: Nettsted for islamske dukker: Den tyrkiske dukken Elif; Hentet 26.08.2014 fra http://sweetness-light.com/archive/koran-reciting-doll-replaces-barbiein-turkey, og den indonesiske barbiedukken Salma; Hentet 26.08.2014 fra http://sweetness-light.com/archive/indonesian-introduces-an-islamic-barbie-doll

Tatchell, Jo: Meet the Islamic Barbie, The Guardian 30. september 2004; Hentet 09.04.2014 fra http://shopping.guardian.co.uk/toys/story/0,1316478,00.html

Zoepf, Katherine: Bestseller in Mideast: Barbie With a Prayer Mat, New York Times, Damascus Journal, 22. september 2005; Hentet 26.08.2014 fra http://www.nytimes.com/2005/09/22/international/middleeast/22doll.html?_r=1\&oref =slogin

\footnotetext{
${ }^{1}$ En lengre redegjørelse om taswir-problematikken finnes i doktorgradsavhandlingen Taswir i norsk kontekst: En unders $\phi$ kelse av hvordan unge norskpakistanske muslimer forholder seg til visuell kommunikasjon med figurative uttrykk. Kildetekstene i denne artikkelen er sitert fra Abu Mohammed Abdur-Ra'uf Shakirs bok The Islamic Ruling Concerning At-Tasweer fra 1998. I artikkelen er arabiske begreper transliterert til latinsk alfabet i en forenklet versjon av det systemet som brukes i International Journal of the Middle East Studies (IJMES), og dette avviker fra systemet brukt i kildetekstene. Bokstaveringen av samme begrep varierer derfor i enkelte tilfeller. I artikkelen brukes begrepet «lærd» om fortolkere med ulik bakgrunn.

${ }^{2}$ Allerede Ibn Taymiyya (1263-1328) kommenterte hodets betydning i et bilde. Se Ibn Baz' fatwa om taswir på nettstedet World of Islam http://islamicarticles.wordpress.com/tasweer/. The Qur'an and Sunnah Society understreker at bilder av ansiktstrekk må unngås, http://www.qss.org/questions/data/Fundamentals_Haraam.html.

${ }^{3}$ Aisha Dolls http://aishadolls.com/. Se også Islam QA, Question \& Answer der det understrekes at dukker bør være av ull, og uten ansikt, http://www.islamqa.com/index.php?ref=9473\&In=eng. For andre typer dukker beregnet på det islamske markedssegment, se Simply Islam http://www.simplyislam.com/iteminfo.asp?item=55030, og barbiedukkevariantene, for eksempel syriske Fulla, som kommer med egen bønnematte, http://www.nytimes.com/2005/09/22/international/middleeast/22doll.html?_r=1\&oref=slogin, indonesiske Salma, http://sweetness-light.com/archive/indonesian-introduces-an-islamic-barbie-doll og amerikanske Razanne i tre varianter (lyshudet med blondt hår, lyshudet med mørkt hår og mørkhudet), http://shopping.guardian.co.uk/toys/story/0,,1316478,00.html.

${ }^{4}$ Argumentet om betydningen av bildets plassering skal først ha vært utviklet av Hanafi-juristen Abu Jafar al-Tahawi (død 935). Det kan blant annet refereres til IslamOnline, Fatwa Bank: Fatwa on Pictures on Clothes http://www.islamonline.net, Ummah Forum http://www.ummah.net/forum/showthread.php?t=31303, Sunnah Online http://www.sunnahonline.com/ og det norske nettstedet Islam.no, Spørsmål og svar: Bilder, http://www.islam.no.

${ }^{5}$ På nettstedet Islam QA, Question \& Answer hevdes det at bilder kan lede til shirk, http://www.islamqa.com/index.php?ref=26841\&ln=eng\&txt=photo, se dessuten IslamiCity Forum http://www.islamicity.com/forum/forum posts.asp?TID=5048\&PN=8. På Ummah Forum blir bilder forbundet med shirk og hedendom, http://www.ummah.net/forum/showthread.php?t=31303.
} 
${ }^{6}$ Historien er gjengitt i Our Dialogue, Arab News, Jeddah 22. november 2005,

http://www.ourdialogue.com/answers/articles.php?action=show\&showarticle=1130. Se dessuten Our Dialogue http://www.ourdialogue.com/answers/articles.php?action=show\&showarticle=1129.

${ }^{7}$ Slike synspunkter hevdes for eksempel innenfor wahhabisme og salafist-retninger. På flere nettsteder kommer det klart til uttrykk at fotografiet, som medium, ansees som forbudt, for eksempel på Islam QA, Question \& Answer http://www.islamqa.com/index.php?ref=82366\&ln=eng\&txt=photo, Ummah Forum

http://www.ummah.net/forum/showthread.php?t=31303, IslamiCity Forum http://www.islamicity.com/forum/forum posts.asp?TID $=5048 \& \mathrm{PN}=8$

${ }^{8}$ IslamOnline, Fatwa Bank: I Fatwa on Photography 16. september 2003 utredes fotografiet generelt. I Keeping Framed Pictures 20. oktober 2002 tillates familiefotografier på visse betingelser. Vurderingene er foretatt av indisk-kanadiske Ahmad Kutty, http://www.islamonline.net. Det norske nettstedet Islam.no fremhever at det finnes delte meninger om fotografi. Det er ikke problematisk å ha fotografier av venner og slektninger på veggen, men det må alltid tas hensyn til bildenes art og påvirkningskraft, Spørsmål og svar: Billedforbud i islam? og Bilder http://www.islam.no.

${ }^{9}$ Om at bilder for hyggens skyld frarådes, mens nyttige bilder tillates: Islam QA, Question \& Answer http://www.islamqa.com/index.php?ref=88180\&ln=eng\&txt=photo.

${ }^{10}$ Den lærde Ibn 'Uthaymin skal ha vært den som utformet argumentene i favør av levende bilder: Islam Qa, Question \& Answer om hvorfor levende bilder vurderes annerledes enn fotografiet, http://www.islamqa.com/index.php?ref=88180\&ln=eng\&txt=photo, http://www.islamqa.com/index.php?ref=91356\&ln=eng\&txt=photo. Our Dialogue slår fast at dataspill er uproblematisk dersom tema og motiver ikke er upassende, http://www.ourdialogue.com/answers/articles.php?action=show\&showarticle=139. Andre mener at levende bilder, formidlet gjennom for eksempel TV, ikke er tillatt. Dette synspunktet hevdes på Islamic Network http://www.islaam.net/display/display.php?category=20\&id=177. 